\title{
Female genital mutilation: barriers to accessing care
}

\author{
(C) $\mathbb{( 1 ) \Theta}$ OPEN ACCESS
}

\section{Sharon Dixon FGM lead, Joy Shacklock RCGP clinical champion good practice safeguarding, Jonathan Leach joint honorary secretary}

Royal College of General Practitioners, London NW1 2FB, UK

We thank Creighton and colleagues for their editorial. ${ }^{1}$ Women affected by female genital mutilation (FGM) describe barriers to accessing medical care in the UK, including fear of judgment by health professionals. ${ }^{2}$ Recent policy changes, including mandatory reporting and the FGM enhanced dataset, may increase reluctance to see doctors. ${ }^{34}$

Trust and confidentiality are cornerstones of consultations. Where there are safeguarding concerns, relevant proportionate information should rightly be shared with the relevant agencies. But treating FGM differently from other safeguarding issues risks perceptions of discriminatory judgments and cultural bias. If this contributes to missed opportunities to support women and families from communities affected by FGM, we may be less able to meet their health and safeguarding needs.

From a primary care perspective, we have concerns about the FGM information sharing system. This policy places an alert on the summary care record of the female children of women identified as having FGM. ${ }^{5}$ This alert will be visible in primary care consultations, without linkage to the safeguarding assessments that were done surrounding this.

In implementation, the alert recording a family history of FGM will likely be placed on the newborn child's records by maternity professionals. But primary care holds the ongoing relationship with the child and family. When the child presents with a routine minor illness and the alert appears, how should clinicians respond? We are concerned that repeated questioning risks deterring the family from seeking healthcare in future.

We appreciate and agree with the united policy aims to support communities to eliminate FGM, to provide care for women, and to safeguard their families. We are concerned that, despite having not evaluated the effectiveness or unintended effects of mandatory reporting in FGM, the Home Office has subsequently consulted on introducing mandatory reporting for forced marriage. $^{6}$

Disproportionate measures risk being perceived as discriminatory and may ultimately be counterproductive.

Competing interests: SD is a trustee of Oxford Against Cutting.

Full response at: https://www.bmj.com/content/364/bmj.115/rr-2.

Creighton SM, Samuel Z, Otoo-Oyortey N, Hodes D. Tackling female genital mutilation in the UK. BMJ 2019;364:115. 10.1136/bmj.115 30617106

2 Norman K, Hemmings J, Hussein E, Otoo-Oyortey N. FGM is always with us. Experiences, perceptions and beliefs of women affected by female genital mutilation in London. FORWARD, 2009.

3 Plugge E, Adam S, El Hindi L, Gitau J, Shodunke N, Mohamed-Ahmed O. The prevention of female genital mutilation in England: what can be done?J Public Health (Oxf) 2018. 10.1093/pubmed/fdy128 30060003

4 Oxford Against Cutting. A pilot evaluation of health services for communities affected by FGM/C in Oxfordshire Oxford Against Cutting A Healthwatch Oxfordshire Project Fund report. Healthwatch Oxfordshire, 2016.

5 NHS Digital. Female genital mutilation-information sharing. https://digital.nhs.uk/services/ female-genital-mutilation-risk-indication-system-fgm-ris

Home Office. Preventing and tackling forced marriage. https://www.gov.uk/government/ consultations/preventing-and-tackling-forced-marriage

Published by the BMJ Publishing Group Limited. For permission to use (where not already granted under a licence) please go to http://group.bmj.com/group/rights-licensing/ permissionsThis is an Open Access article distributed in accordance with the Creative Commons Attribution Non Commercial (CC BY-NC 4.0) license, which permits others to distribute, remix, adapt, build upon this work non-commercially, and license their derivative works on different terms, provided the original work is properly cited and the use is non-commercial. See: http://creativecommons.org/licenses/by-nc/4.0/. 